\section{Military College of Science :}

Prof. A. Porter

Prof. Arthur Porter, professor of instrument technology in the Military College of Science, Shrivenham, has left to take up the post of director of research in the Canadian branch of Ferranti, Ltd. Prof. Porter is a graduate of the University of Manchester. During the period 1933-37 he worked under the direction of Prof. D. R. Hartree on the development and application of the Manchester differential analyser. This machine, which was the first of its kind to be built outside the United States, was applied to a wide variety of problems ranging from the determination of atomic wave functions by the method of self-consistent fields on one hand, to the study of non-linear electrical networks and terminated transmission lines on the other. After serving as assistant lecturer in physics during 1936-37, Dr. Porter obtained a Commonwealth Fund Fellowship and worked under Dr. Vannevar Bush at the Massachusetts Institute of Technology during 193739 on the development of the 30-integrator Rockefeller differential analyser. During the Second World War he worked in various government research establishments, including the Admiralty Research Laboratory, the Army Operations Research Group, and the Radar Research and Development Establishment, on anti-aircraft fire control and related problems. His main interest was the study of automatic and manual control systems and their application in military and industrial instruments and processes. He was secretary of the Ministry of Supply Servo Panel during its existence (1942-45), and he was also the secretary of the Interdepartmental Technical Committee on Servo Mechanisms from its inception in 1944. In May 1946 he joined the National Physical Laboratory and started a new section on automatic control problems, with particular reference to industrial applications. Porter joined the Military College of Science in October 1946, to be the first occupant of the new chair of instrument technology, and immediately threw himself into the very considerable task of organising courses in instrument technology and engineering physics and in establishing laboratories for these new subjects. While the courses and laboratories are not yet in a settled state, they do represent a very fine achievement for so short a time.

Mr. C. Holt Smith

MR. C.'HoLt SMITH has been appointed professor of instrument technology at the Military College of Science in succession to Prof. A. Porter. After completing his studies at the University of Manchester, where he took the degree of B.Sc., and serving an engineering apprenticeship, Mr. Holt Smith entered the Radio Department of the Royal Aircraft Establishment in 1926. His first work there was in connexion with microphones for use in aircraft, to which he made valuable contribution. At a later stage he turned his interest towards direction finding, and invented an automatic direction-finding system which was one of the earliest in the field. For a period he left government service and worked in the research department of the British Broadcasting Corporation, returning to government service in 1938. On his return he became responsible for the direction-finding and navigation work at the Royal Aircraft Establishment, in particular for the direction-finding equipment that was developed for Fighter Command. He then spent some two years at the Telecommunications Research Establishment on antenna research, afterwards serving for a little over a year as assistant director at Headquarters. He returned later to take charge of a flying unit which provided the flying facilities for the Establishment, including the special installation of radar equipment in aircraft. Eventually he became head of the Radio Department there, and as such has been responsible for research and development on airborne and ground radar systems, including radar types of navigational aids, not only for the Fighting Services but also for the Ministry of Civil Aviation.

\section{Tribute to Prof. M. von Laue, For.Mem.R.S.}

Prof. Max von LaUE's seventieth birthday on October 9, 1949, was an occasion of celebration among German physicists and the world of seience at large. Prof. A. Sommerfeld wrote in the Physikalische Blaetter that the best way of characterizing him is to call him the most outstanding and the most faithful of Planck's pupils. Laue received his doctor's degree from Planck in 1903, became Planck's assistant in 1905 , and the two men always remained close friends. In 1909, Laue went as a lecturer to Munich where, as he puts it, "the atmosphere was saturated with the question whether $\mathrm{X}$-rays were corpuscles or waves", a question which his own discovery soon settled. In 1912, he received the Nobel Prize for it. A tribute to Laue which Sir Lawrence Bragg sent to the Physikalische Blaetter includes the following: "I feel that of all living scientists $I$ owe most to Professor Laue for making this discovery. I was just starting my career when it was announced; it decided the subject of my very first researches, and it has formed the basis of my scientific work ever since. This discovery opened up new vistas, a new science has been born as a result of it. . . By his kindness, his courtesy, his courage, and his staunch adherence to his principles, he has gained international affection and esteem as well as international fame. ..." Laue proved his courage and staunch adherence to principle during the Hitler regime, and he drew upon himself the wrath of Nazi men of science when he dared, in an obituary, to praise the great merits of Fritz Haber, who had died in exile. When Laue was in America in 1948, he wrote home: "On November 2, I received here in Chicago a honorary doctor's degree. The diploma describes me as 'a physicist and resolute champion of freedom', of which I am very proud. The International Union of Crystallography which, owing to its connexion with the United Nations, may not elect a German to its Board, has made me honorary president for life, and the American Physical Society an honorary member." Recently, Laue was elected a foreign member of the Royal Society (see Nature, May 21, p. 794).

\section{Manufacture, Properties and Uses of Toughened Glass}

A 16-mm. film on the manufacture, properties and uses of toughened glass was recently shown in London by Pilkington Brothers, Ltd., the manufacturers of 'Armourplate' and 'Armourlight' glasses. The film shows how, following the principle of 'Rupert's drop', glass plate can be toughened by heating to softening point and then rapidly cooling both sides with jets of cold air. The exterior surfaces contract on cooling, but the interior remains hot and plastic and yields 